\title{
The Impact of the Interaction between Madden-Julian Oscillation and Cold Surge, on Rainfall over Western Indonesia
}

\author{
Agita Vivi Wijayanti ${ }^{1}$, Rahmat Hidayat ${ }^{\star 2}$, Akhmad Faqih ${ }^{3}$ and Furqon Alfahmi ${ }^{4}$ \\ ${ }^{123}$ Department of Geophysics and Meteorology, IPB, ${ }^{4}$ Agency for Meteoorlogy, CLimatology, and Geophysics
}

Received: 2021-03-02 Accepted: 2021-06-03

Keywords:

MJO;

CS;

rainfall observation; wind anomalies

Correspondent email: agitavivi@apps.ipb.ac.id

\begin{abstract}
The Madden-Julian Oscillation and Cold Surge phenomena have been known to cause increased rainfall, with the capacity to trigger hydrometeorological disasters, in western Indonesia. However, further investigations are required regarding the interaction between these phenomena on rainfall pattern. Therefore, this study aims to analyze the interaction between MJO and CS over western Indonesia, particularly by using land-based rainfall observation data from multiple stations, as previous studies were dominated by the use of gridded data from remote observations. This study utilized in-situ observation data obtained from 4329 weather observations and rain stations between 1989 and 2018 . Subsequently, quality control performed based on data availability exceeding $70 \%$ over a 30 -year period resulted in 303 selected stations to be used for further analysis. Meanwhile, the RMM index, as well as reanalysis data of mean sea level pressure and $925 \mathrm{hPa}$ meridional wind, were also applied for MJO and CS identification. According to the composite analysis, the effect of CS on MJO phases tends to increase precipitation by about $50 \%$, over western Indonesia, with maximum increase ranging from 200 to $400 \%$ over the northeastern coast of Sumatra, around Karimata Strait (Riau Islands and West Kalimantan), as well as the northern coast of Java. These areas are exposed to the sea and have direct access to the wind-terrain interaction. In addition, the highest rainfall anomaly due to the MJO-CS interaction occurs around Karimata Strait, followed by northern Sumatra and Java, with spatially averaged rainfall anomaly reaching $5 \mathrm{~mm} /$ day over the area.
\end{abstract}

2021 by the authors. Licensee Indonesian Journal of Geography, Indonesia

This article is an open access article distributed under the terms and conditions of the Creative Common
Attribution(CC BY NC) licensehttps://creativecommons.org/licenses/by-nc/4.0/.

\section{Introduction}

The surplus of solar radiation energy over the tropics, as well as the abundant water vapour availability from the oceans trigger clouds formations, and this produces significant rainfall over the Indonesian Maritime Continent (IMC). This region's high rainfall intensity is often produced by Mesoscale Convective Systems (MCS) (Choi et al., 2011; Doswell et al., 1996; Jong Hoon Jeong et al., 2016; Nuryanto et al., 2019), supported by a series of weather and climate variabilities, including the Madden-Julian Oscillation (MJO; Hidayat, 2016; Pramuwardani et al., 2018) and Cold Surge (CS; Chang and Lau, 1979; Lim et al., 2017; Wang et al., 2012).

Furthermore, the $\mathrm{MJO}$ is proven to trigger extreme rainfall over most parts of Indonesia (Hidayat, 2016; Pramuwardani et al., 2018; Wu et al., 2013), and this is often followed by floods (Sudiar, 2013), leading to loss and damage in the affected region. Tung et al., (2014) defined the MJO as a dominant convective system in the tropics, propagating from west to east, with a sub-seasonal period around 20-90 days. Generally, the MJO's phase is formed and begins from the Indian Ocean (Zhang and Ling, 2017). These convective cloud clusters then move eastward with an average speed of 5 $\mathrm{m} \mathrm{s}^{-1}$ (Lafleur et al., 2015), until they reach the central Pacific Ocean.

The MJO's location and amplitude is analyzed from the MJO Real-time Multivariate Index (RMM; Wheeler and
Hendon, 2004), obtained from the Empirical Orthogonal Function (EOF) analysis. This index is calculated using daily Outgoing Longwave Radiation (OLR) data, as well as 850 and $200 \mathrm{hPa}$ zonal wind over the equatorial region $\left(15^{\circ} \mathrm{N}-15^{\circ} \mathrm{S}\right)$, by first eliminating cycles, seasonal, and annual variability in each data. RMM index is considered capable of capturing MJO's evolution along the equator without using conventional time-filtering methods (Jee Hoon Jeong et al., 2005), and was therefore widely used in MJO-related studies (Jee Hoon Jeong et al., 2005; Lafleur et al., 2015; Lim et al., 2017; Rauniyar and Walsh, 2011; Wang et al., 2012; Zhang and Ling, 2017).

The rise in convective activity over IMC is also closely related to the phenomenon of cold air surging off the Asian continent, referred to as "Cold Surge" (Chang and Lau, 1979), impacting rainfall variability, especially over western Indonesia. CS's (Cold Surge) definition is derived from the lower wind levels in southern China, the South China Sea, and the tropical West Pacific occurring the Asian monsoon's increasing intensity during winter (Chang and Lau, 1979). Simply put, CS is a stronger monsoon wind flowing southwards from the Asian continent, carrying cold air masses. Despite originating as an extra-tropical disturbance, CS is able to spread to the tropics and amplify convection over the region (Abdillah et al., 2021; Chang and Lau, 1979; Wang et al., 2012). Therefore, CS has a significant effect 
around the southern South China Sea, 's southern for increasing convergence in the lower layers, and increases vorticity around the Borneo Island (Chang et al., 2016; Lim et al., 2017).

Due to different motion orientation between MJO and CS (zonal and meridional), the interaction between these two phenomena is of interest for further investigation, and has been studied widely (Abdillah et al., 2018, 2021; Chang et al., 2005; Jee Hoon Jeong et al., 2005; Pang et al., 2018; Wang et al., 2012). Furthermore, the interaction between MJO and CS triggered a higher increase in the rainfall over western Indonesia, compared to situations where only one of the two phenomena occurred over the area (Hattori et al., 2011; Lim et al., 2017). The MJO provides favourable conditions as CS' precursor (Abdillah et al., 2021) and for CS to amplify (Jee Hoon Jeong et al., 2005; Lim et al., 2017; Pullen et al., 2015), and possibly contribute as an essential lower-tropospheric factor for MJO initiation (Wang et al., 2012), as well as propagation through the MC (Pang et al., 2018). Generally, MJO and CS-related studies are conducted on a larger scale, by utilizing grid data from remote sensing (satellite). This data is beneficial, easy to access, and widely used, but is unable to capture a small pattern or produce the best accuracy. Therefore, as a continuation of previous research, this study aims to analyze the land-based rainfall pattern due to the interaction of $\mathrm{MJO}$ and $\mathrm{CS}$ in western Indonesia, to obtain more precise results as well as an improved understanding of the interaction.

\section{Methods}

This study requires three main data to be successful. The first required data is the Real-time Multivariate MJO Index for entire study periods obtainable from the IRI Data Library for free. Furthermore, the second is the ERA-Interim Reanalysis dataset (Dee et al., 2011) for mean sea level pressure (MSLP) and $925 \mathrm{hPa}$ meridional wind with four time-steps $(00,06,12,18)$ for identifying CS days, as well as eight levels $(100,200,300,500,700,850,925,1000 \mathrm{hPa})$ of zonal and meridional winds, to calculate the vorticity and wind anomalies, with region covers $35.0^{\circ} \mathrm{N} 105.0^{\circ} \mathrm{E} 10.0^{\circ} \mathrm{S}$ $120.0^{\circ} \mathrm{E}$ and a $0.125^{\circ}$ resolution, for a period of 30 years (1989 - 2018). This is often used to identify CS (Heo et al., 2018; Woo et al., 2012) and is obtainable from European Centre for Medium-Range Weather Forecasts (ECMWF) for free. The third is daily rainfall data from in-situ observation archived by Agency for Meteorology, Climatology, and Geophysics (BMKG) from 4329 points throughout Sumatra, Java, as well as West and Central Kalimantan.

This study began by identifying the MJO active phases along November, December, January, and February (NDJF) 1989-2018. The NDJF period was selected, considering CS activity occurred during Boreal Winter, the airflow uniformity during the Asian Monsoon period, and the period MJO was most prominent (Chen et al., 2017). In addition, most of the study areas generally experienced a significant increase in rainfall during the NDJF period, therefore the presence of MJO and CS was expected to be maximal.

Subsequently, MJO identification was carried out using pentad average of RMM index from 1989-2018, based on three criteria. These criteria were, the RMM index's magnitude must be above one in more than one consecutive pentad, the phases must be sequential, and all requirements must be attained in more than six pentads, with no phase being stationary for more than four pentads (Becker et al., 2011; L'Heureux and Higgins, 2008). Days where these three requirements are attained, are referred to as active MJO days. Meanwhile, Active CS refers to days where the averaged meridional winds along the tracking line at $110^{\circ}-117.5^{\circ} \mathrm{E}$ at $15^{\circ} \mathrm{N}$, flowed southward with a speed above or equal to $8 \mathrm{~m} \mathrm{~s}$ ${ }^{-1}$ (Chang et al., 2005) and were preceded by a MSLP gradient above $10 \mathrm{hPa}$ between Gushi $\left(32^{\circ} 15^{\prime} \mathrm{N} ; 115^{\circ} 40^{\prime} \mathrm{E}\right)$ and Hong Kong $\left(22^{\circ} 18^{\prime} \mathrm{N} ; 113^{\circ} 55^{\prime} \mathrm{E}\right)$, for up to three days prior (Aldrian and Utama, 2010), to consider the time required for CS to flow southward. Figure 1 shows a simplified Scheme of the identification of these two phenomena.

A quality control analysis was conducted on daily rainfall data from 4329 locations throughout Sumatra, Java, West Kalimantan, and Central Kalimantan, by removing data with 0 values for over 100 consecutive days. Subsequently, the accepted were filtered, and only observation points with data availability of $70 \%$ or more between 1989 and 2018, were selected for further analysis. Figure 2 shows this selection resulted in 303 location points.

Furthermore, the 850 zonal and meridional wind reanalysis

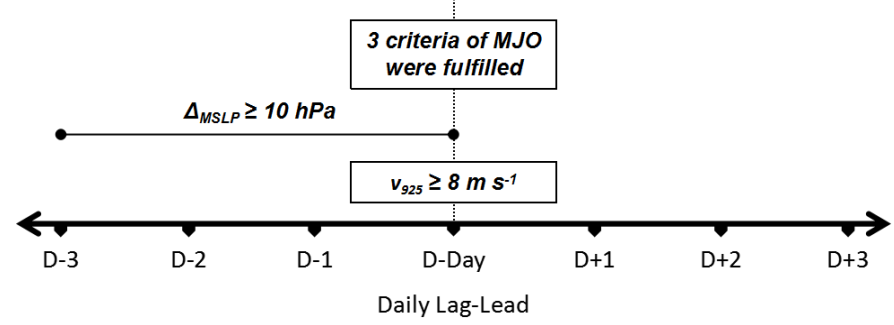

Figure 1. MJO and CS Identification Scheme.

data were used to calculate the absolute vorticity, a measure of the fluid rotation, used to better explain the flow's dynamics, and is closely related to the precipitation (Darand and Mirzaei, 2018; Li et al., 2017). Vorticity also indicated the presence of CS well (Chang et al., 2016; Lim et al., 2017), therefore, vorticity anomalies pattern is also displayed in this study. The positive (negative) vorticity in North Hemisphere (South Hemisphere) possibly act as a proxy for cyclonic movements, trigger increased rainfall, while negative (positive) vorticity in North Hemisphere (South Hemisphere) triggered anti-cyclonic circulation, identical to fair weather. The following equation was used to calculate the absolute vorticity's value (Holton, 2004). Where, $\eta$ represents absolute vorticity $\left(\mathrm{s}^{-1}\right), \partial \mathrm{v} / \partial \mathrm{x}$ denotes the change in meridional wind speed relative to the $\mathrm{x}$-axis, $\partial u / \partial y$ signifies $\eta=\frac{\partial v}{\partial x}-\frac{\partial u}{\partial y}+2 n \sin \varphi$ the change in zonal wind speed relative to the $y$ axis, $\Omega$ connotes the earth rotation's angular speed $\left(7.29 \times 10^{-5}\right.$ $\left.\operatorname{rad~s}^{-1}\right)$, and $\varphi$ indicates latitude $\left({ }^{\circ}\right)$.

Furthermore, composite analysis was conducted on rainfall data, absolute vorticity, as well as $850 \mathrm{hPa}$ zonal and meridional wind, to determine the phenomena's pattern. Subsequently, anomalies were obtained by subtracting the composite value at specific conditions, from the climatological value at corresponding periods (Lim et al., 2017). A Daily-lag analysis was also performed CS's impact on MJO phases and the interaction within the study area. In this study, D-Day refers to the day CS reaches $15^{\circ} \mathrm{N}$ or the day of interaction, where CS and MJO are both active. Therefore, enabling CS's impact on precipitation over the study area to be better traced. Furthermore, spatially 
averaged rainfall anomalies over northern Sumatra, around Karimata Strait, and Java were also compared to identify the more specific area's rainfall pattern. Figure 2 shows these three areas, marked by rectangles $\mathrm{A}, \mathrm{B}$, and $\mathrm{C}$.

\section{Result and Discussion}

Based on MJO identification during NDJF period for 30 years (3600 days as additional days in leap years were
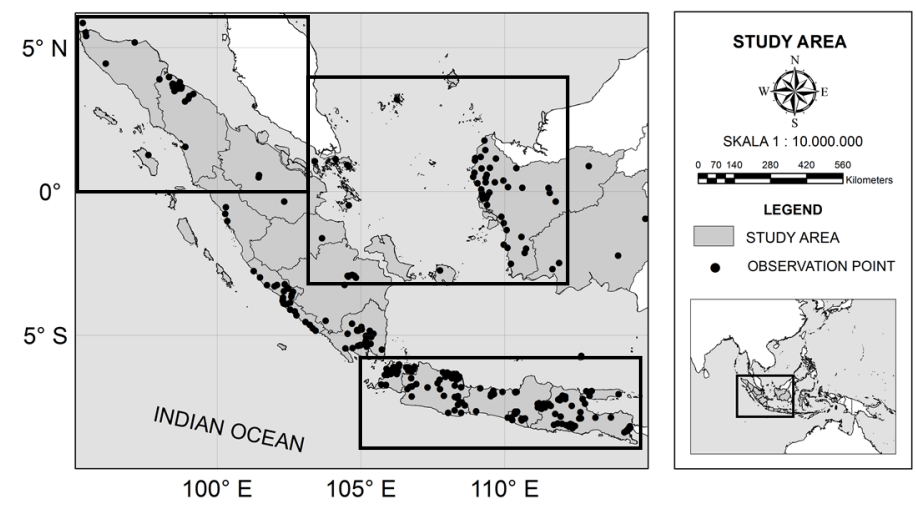

Figure 2. The Study Area

removed), from 1989 to 2018 , MJO was active for 1789 days (49.69\%). Furthermore, of these days, 327 days were active over the Western Hemisphere and Africa, 428 days were over the Indian Ocean, 450 days over the Maritime Continent, while 584 days were over the western Pacific Ocean. This percentage is a bit lower, compared to the study by Jeong et al., (2005), where a total of $51.64 \%$ MJO occurrence was reported. However, this difference is relatable considering the different study periods (NDJFM for Jeong et al., (2005)) and identification techniques, where Jeong et al., (2005) only considered the RMM index's magnitude.

Active CS often accompany active MJO days. During the NDJF season over 30 years, active CS was observed for a total of 1009 days (139 periods), and an active MJO phase was observed to be accompanied for 516 days (14.3\%). Table 1 shows the number of CS days accompanied by MJO in each phase, where MJO was $45.89 \%$ active on phases 5, 6, and 7 .

According to Figure 3, MJO's impact over western Indonesia varies with phase. The diagram shows daily rainfall anomalies for every observation point as scaled on the colour bar. Also, the circle's size represents rainfall intensity at each observation point with a legend on each map's lower left side. Furthermore, there are significant differences between rainfall patterns, once MJO was active in phases 2-4 and 5-7. In phase 2, the study area was dominated by positive anomalies, especially in Sumatra, Kalimantan, and the southern coast of Java. These anomalies remain present once MJO was active in phases 3 and 4, even on the northern coast of Java. MJO's effect on MC was weakened due to barrier effect (Ahn et al., 2020; DeMott et al., 2018; Feng et al., 2015; Kim et al., 2017; Zhang and Ling, 2017), however, the positive composite rainfall anomalies reach $10 \mathrm{~mm} /$ day on some points over phase 4 .

In contrast with phases 2-4, phases 5-7 generally trigger negative rainfall anomalies. These negative anomalies appear after MJO enters phase 5, and are present in most of the study areas, with a daily intensity below $10 \mathrm{~mm}$. During MJO phase 6 , the negative rainfall anomalies become more robust and attain minimum peak, with a subsequent reduction in daily rainfall intensity, to values below $5 \mathrm{~mm}$. However, positive rainfall anomalies begin to appear again over southern Sumatra and Java once MJO enters phase 7. Between Sumatra and Kalimantan, Java appears to be the least region affected by the MJO, both during wet and dry phases. Xavier et al., (2014) and Muhammad et al., (2021) suggested this rise and fall in precipitation or extreme precipitation due to $\mathrm{MJO}$, have an occurrence probability of $20-50 \%$ over Southeast Asia and 40-70\% over western and central Indonesia.

The positive and negative rainfall anomaly patterns over Sumatra and Kalimantan showed by the MJO phase 2-4 and 5-6 are majorly similar to the TRMM 3B42 dataset (Lim et al., 2017) and composite OLR anomaly counterparts (Fujita et al., 2011; Wheeler and Hendon, 2004). However, on the OLR map, positive anomalies indicating suppressed convection began from phase 5 and attained maximum level on phase 7 - 8. This pattern shows a one-phase lag between the OLR and precipitation parameters, where OLR is likely to miss a phase.

Figure 4 shows the composite daily rainfall anomaly and daily rain rate, indicating CS' effect on rainfall over the study area. Anomalous changes in the rainfall shown in the image are less contrasting, compared to changes due to MJO in the previous figure. This condition differs from the statement by Lim et al., (2017), suggesting CS has a higher impact in triggering extreme rainfall, compared to the Madden-Julian Oscillation. A calculation of the rise in precipitation over the sea possibly enables an observation of the increasing precipitation due to CS, mainly over waters around the southern South China Sea and expanding up to Java Sea (Lim et al., 2017). However, MJO has a higher impact and affects a larger area on land, compared to CS. This is because the area receiving CS' direct impact is smaller, compared to MJO, only around Karimata Strait, including Riau Islands and West Kalimantan.

Generally, the area around Karimata Strait has a random rainfall pattern, three to one day before Cold Surge reached

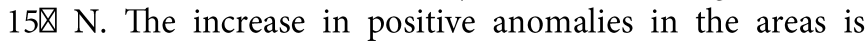
observed to start evenly at D+1, and continues to increase until D+3. This increase is significantly evident over Riau Islands and West Kalimantan.

The effect of the CS is also evident around northern

Table 1. The number of days for each MJO phase

\begin{tabular}{lccccccccc}
\hline \multirow{2}{*}{ Condition } & \multicolumn{1}{c}{ MJO Phase } \\
\cline { 2 - 9 } & 1 & 2 & 3 & 4 & 5 & 6 & 7 & 98 \\
\hline With CS & 36 & 24 & 59 & 65 & 90 & 94 & 50 \\
Without CS & 117 & 158 & 187 & 148 & 147 & 191 & 201 & 124 \\
Total MJO days & 153 & 182 & 246 & 213 & 237 & 285 & 299 \\
\hline
\end{tabular}




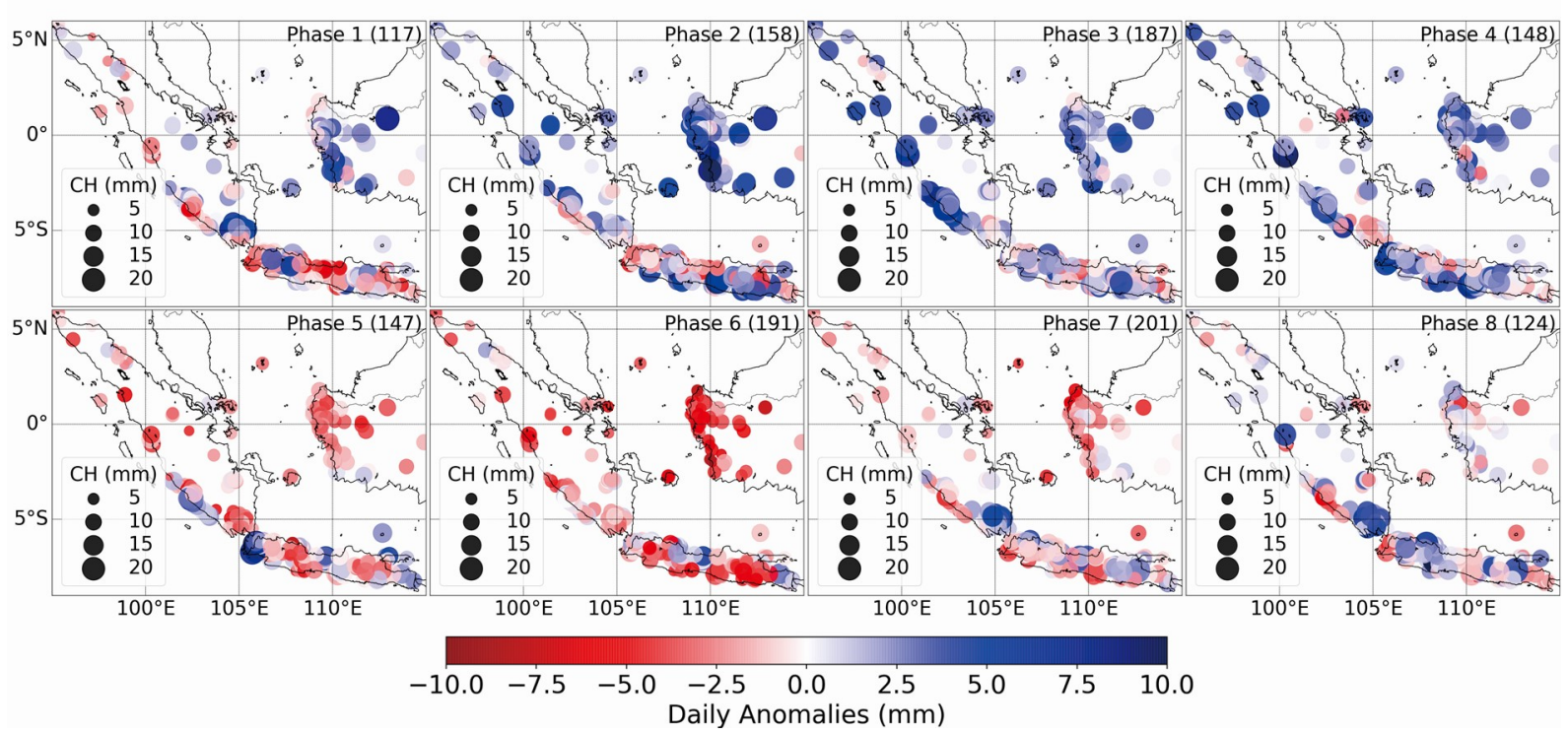

Figure 3. Composite Analyses of daily rainfall (circle size) and rainfall anomaly (shaded) for MJO Phases.

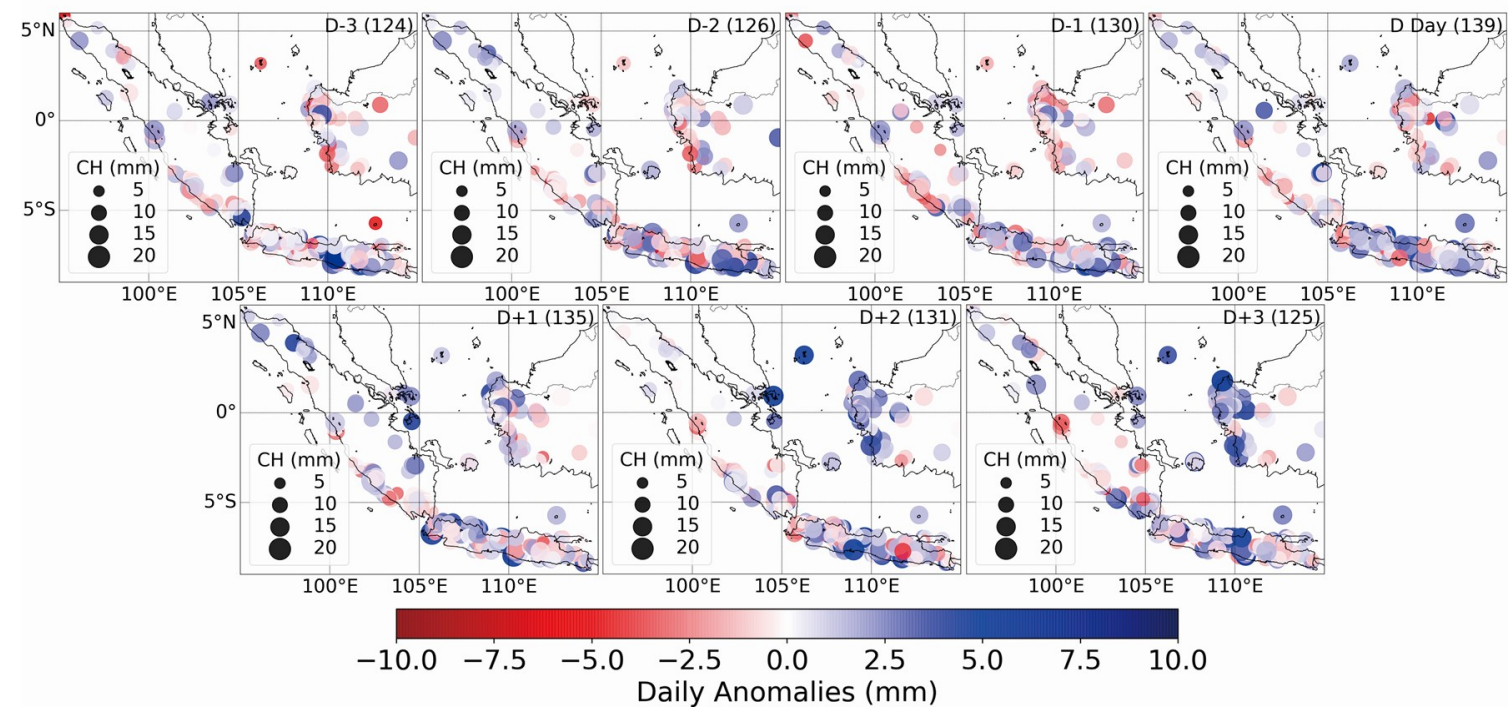

Figure 4. Composite Analyses of rain rate (circle size) and Rainfall Anomaly (shaded) due to CS from D-3 to $\mathrm{D}+3$ after the flow reached $15^{\circ} \mathrm{N}$.

Sumatra, where the average rain rate around the region $\left(95^{\circ} \mathrm{E}\right.$ $-103^{0} \mathrm{E} ; 0^{0}-6^{0} \mathrm{~N}$ ) before CS reached $15^{0} \mathrm{~N}$ was $6.69 \mathrm{~mm} /$ day. This value was discovered to increase to $6.76 \mathrm{~mm} /$ day after $\mathrm{CS}$ reached $15^{\circ} \mathrm{N}$, therefore, a rise of about $0.07 \mathrm{~mm} /$ day was observed. Meanwhile, around Karimata Strait, a higher increase in average rain rate of up to $0.86 \mathrm{~mm} / \mathrm{day}$, was detected over the region $\left(103^{\circ} \mathrm{E}-112^{\circ} \mathrm{E} ; 3^{0} \mathrm{~S}-4^{\circ} \mathrm{N}\right)$. However, Figure 4 indicates the increased rainfall is centered towards the northern region, thus, a higher increase of up to 1.21 $\mathrm{mm}$ /day was observed for the $103^{\circ} \mathrm{E}-110^{\circ} \mathrm{E} ; 2^{\circ} \mathrm{S}-4^{0} \mathrm{~N}$ region.

Wind-terrain interaction is likely to have a more significant impact on Cold Surge. As previously mentioned, CS was defined from the lower level wind $(925 \mathrm{hPa})$, and this wind was more likely to deal with higher land surfaces as a terrain. Therefore, a rapid rise is bound to occur due to the wind-terrain effect, as well as a triggering upward movement, increasing rainfall possibility. This statement is consistent with previous studies (Chang et al., 2005; Lim et al., 2017), reporting maximum rainfall intensity on the terrain's windward side.
A boxplot of observed rainfall with an intensity of $1 \mathrm{~mm} /$ day or above in each MJO phase (Figure 5 left) for the entire period and observation points, shows the increasing mean (green triangle) and maximum values (without outliers) in cases where MJO was active on phase 2 and 3 . The maximum value begins to decrease on entering phase 4 and attains minimum value on phase 5 . Furthermore, this pattern was quite similar considering the outliers, denoting extreme events. Maximum outliers' value is achieved on phase 3, while the minimum counterpart occurs on phase 7 . However, outliers' patterns for each MJO phase captured decreasing rainfall over the study area, once MJO was active in phase 5. In addition, the daily time lag boxplot from three days to three days after CS reached $15^{\circ} \mathrm{N}$ (Figure 5 right) shows an increasing pattern in maximum observed rainfall on the $D$ day, and this pattern was persistent three days after. However, in terms of the outliers, increasing rainfall occurs one day after CS reaches $15^{\circ} \mathrm{N}$, with decreasing consistency two days afterward.

The interaction between Cold Surge and Madden-Julian Oscillation phases was analyzed to determine the rainfall 

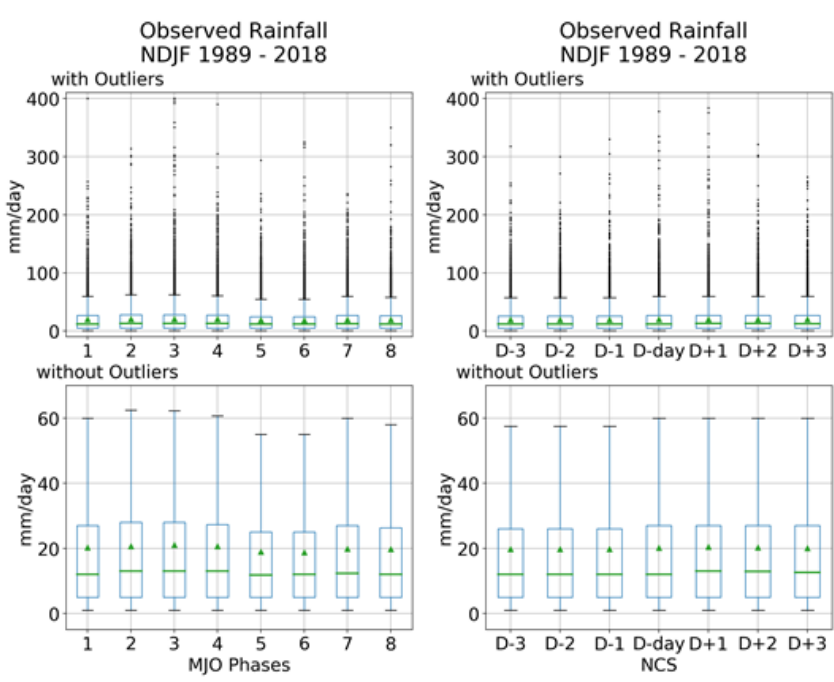

Figure 5. The boxplot of observed rainfall for each MJO phases (left) and daily time lag for CS (right).

pattern from the D-day until three days after. Figure 6 shows a spatial mapping of the changes in rainfall due to CS on the phases, relative to the MJO days. The value was calculated by subtracting the rain rate in the interaction between CS and $\mathrm{MJO}$, from the rain rate where only $\mathrm{MJO}$ was active, diving the result with the rain rate where only MJO active, and multiplied the value by 100 . Each map's lower left section displays the spatially averaged percentage of increasing and decreasing rain rate due to CS on MJO phases, while the upper and lower centers show the maximum and minimum values, respectively.

The average rise in rain rate over the study area ranges from 29 to $68 \%$, while the reduction in rain rate (marked by negative value), ranges from about $21-43 \%$. However, the maximum rise increase in rain rate due to CS is about 109 $475 \%$, while the most significant decrease ranges from about $59-100 \%$. In this study, a significant increase in rainfall due to CS's effect on MJO was mainly detected on the $D$-day to one day after the interaction, but in phases 6 and 7, these increases were detected to last until D+3.

Figure 6 shows 24 maps, and 20 of these maps show maximum increase in rain rate achieved by observation points around the north and west coast, likely to be directly connected to the sea. Among these 20 maps, 11 maps show the maximum increasing rain rate on northern Sumatra, 8 show the maximum value around Karimata Strait (Riau Islands and West Kalimantan), while 1 shows the maximum value over the northern coast of Java. This shows the three regions where CS' presence on MJO's wet and dry phases over western Indonesia are probably have the most significant impact.

Figure 7 shows the spatially averaged rainfall anomaly due to the interaction between these two phenomena, over the northern Sumatra, around Karimata Strait, and Java from the D-Day up to $D+3$, on every MJO phase. Northern Sumatra, around Karimata Strait, and Java were selected for further analyses, because these regions are expected to have a higher impact due to the interaction of MJO and CS as suggested by Hattori et al., (2011), except northern Sumatra, obtaining lesser attention before.

The matrix's first three rows show the interaction between CS and MJO wet days on phases 2-4, the following three rows show the interaction on MJO dry days on phases 5-7, while the last two rows show interaction for periods where MJO has a less significant effect on western Indonesia. Furthermore, the interaction between CS and MJO wet phase appears to give the most significant rainfall anomalies over these regions. In this interaction, positive rainfall anomalies dominated over the regions. The area around Karimata Strait is the most influenced region with a maximum rainfall anomaly up to $5 \mathrm{~mm} /$ day on the day CS and MJO phase 2 interact. This is followed by Northern Sumatra, with a maximum averaged rainfall anomaly of up to $4 \mathrm{~mm} /$ day, in the interaction between MJO wet phase and CS on the $D$ Day. Meanwhile, Java being the least affected region among the others with a maximum averaged rainfall anomaly of 2.0 $\mathrm{mm} /$ day, attained a day after the interaction between CS and MJO phase 4. In addition to the interaction between CS and MJO wet phase, a significant rainfall anomaly was detected over northern Sumatra a day after MJO phase 8 and CS interact. This $4.4 \mathrm{~mm} /$ day rainfall anomaly is probably most affected by CS, as MJO phase 8's effect over northern Sumatra was less significant.

Figure 7 also shows MJO's dominance over CS. Along with the MJO dry phase over western Indonesia, even on the interaction with CS, northern Sumatra, regions around Karimata Strait and Java are mainly dominated by negative rainfall anomalies, with the highest values achieved in Java, two days after the interaction between Cold Surge and Madden-Julian Oscillation phase 7. Also, in the interaction

\begin{tabular}{|c|c|c|c|c|}
\hline \multicolumn{5}{|c|}{$\begin{array}{l}\text { Northern Sumatra } \\
95^{\circ}-103^{\circ} \mathrm{E} ; 0^{\circ}-6^{\circ} \mathrm{N}\end{array}$} \\
\hline 2. & 0.2 & 1.4 & -0.1 & -0.6 \\
\hline 3. & 4.0 & 3.5 & 2.5 & 3.3 \\
\hline & -0.9 & -1.1 & -0.9 & -1.1 \\
\hline & -1.1 & 0.5 & 0.1 & -0.7 \\
\hline & 0.1 & 1.1 & -0.5 & 0.3 \\
\hline 7 & 0.3 & 0.0 & -0.1 & 1.1 \\
\hline 8. & 1.4 & 4.4 & 3.1 & 0.8 \\
\hline 1 & -1.4 & 0.8 & 1.3 & 1.8 \\
\hline & D-Day & $D+1$ & $D+2$ & $D+3$ \\
\hline
\end{tabular}

Karimata Strait
\begin{tabular}{|c|c|c|c|}
\hline $03^{\circ}-112^{\circ} \mathrm{E} ; 3^{\circ} \mathrm{S}-4^{\circ} \mathrm{N}$ \\
\hline 5.0 & 4.4 & 3.3 & 2.6 \\
\hline 3.2 & 4.6 & 1.9 & 1.2 \\
3.7 & 1.8 & -0.2 & 0.1 \\
\hline-0.6 & -0.4 & -1.9 & -2.8 \\
\hline-2.8 & -2.6 & -3.0 & -2.3 \\
\hline-1.3 & -1.4 & -0.7 & -1.7 \\
-0.8 & -2.3 & -1.6 & -1.3 \\
0.3 & 2.3 & 1.5 & 1.1 \\
\hline D-Day & D+1 & $\mathrm{D}+2$ & $\mathrm{D}+3$ \\
\hline
\end{tabular}

\begin{tabular}{|c|c|c|c|c|}
\hline $\begin{array}{l}\text { ava } \\
\left.105^{\circ}-1\right]\end{array}$ & $E ; 6^{\circ}$ & & & \\
\hline-1.0 & 0.9 & 1.1 & -1.8 & \\
\hline 1.7 & 1.4 & 1.7 & -0.1 & 1.0 \\
\hline 0.3 & 2.0 & 0.9 & 1.1 & \\
\hline 1.3 & -0.5 & -1.6 & -1.5 & \\
\hline-1.2 & -1.3 & -0.2 & 0.3 & 0.0 \\
\hline 1.1 & 1.0 & 1.5 & -0.7 & $\overline{\bar{\sigma}}$ \\
\hline-0.5 & 0.1 & -0.6 & -1.0 & \\
\hline-1.7 & -0.2 & -0.6 & -1.2 & \\
\hline D-Day & $D+1$ & $D+2$ & $D+3$ & \\
\hline
\end{tabular}

Figure 7. Spatially Averaged Rainfall Anomaly due to CS on MJO Phases, for Northern Sumatra (left), around Karimata Strait (center), and Northern Java (right). 
between MJO dry phase and CS, minimum rainfall anomaly was achieved, with a value of $-3 \mathrm{~mm} /$ day, around Karimata Strait.

Dynamically, $850 \mathrm{hPa}$ wind anomalies on the day CS and MJO phase 2-7 interact, up to three days after (Figure 8), show MJO circulation's dominance over western Indonesia. The easterlies dominate the area in the interaction between CS and MJO phases 2 and 3. Subsequently, the easterlies shift into westerlies as MJO's convective clusters passed the region, on the interaction between CS and MJO phase 4, leaving the westerlies behind (Wheeler and Hendon, 2004). In comparison with the positive rainfall anomalies, this is a one to two phases lag, where the positive rainfall anomalies begin to dominate the region on phases 2 and 3. This lag appears to be affected by the vanguard effect, leading the precipitation to jump ahead of the main MJO (Matthews et al., 2013; Peatman et al., 2014).

The westerly wind anomalies strengthen in MJO phase 5's interaction and begin to weaken in phase 6. Furthermore, the presence of northerly anomalies from CS are evident in MJO phase 7 , in cases where MJO significantly loses the effect over western Indonesia, with maximum speed of about $2 \mathrm{~m} \mathrm{~s}^{-1}$. MJO's dynamical dominance over CS appears to be affected by the opposed wind pattern between these two variabilities (Chang et al., 2005). A report by Lim et al., (2017) confirmed the result by the southwesterly anomalies occupied the area and partially countered the northeasterly Cold Surge winds, stating during the periods, in contrast to the statement by Pang et al., (2018) suggesting the northeasterly or northerly anomalies dominated the South China Sea and western

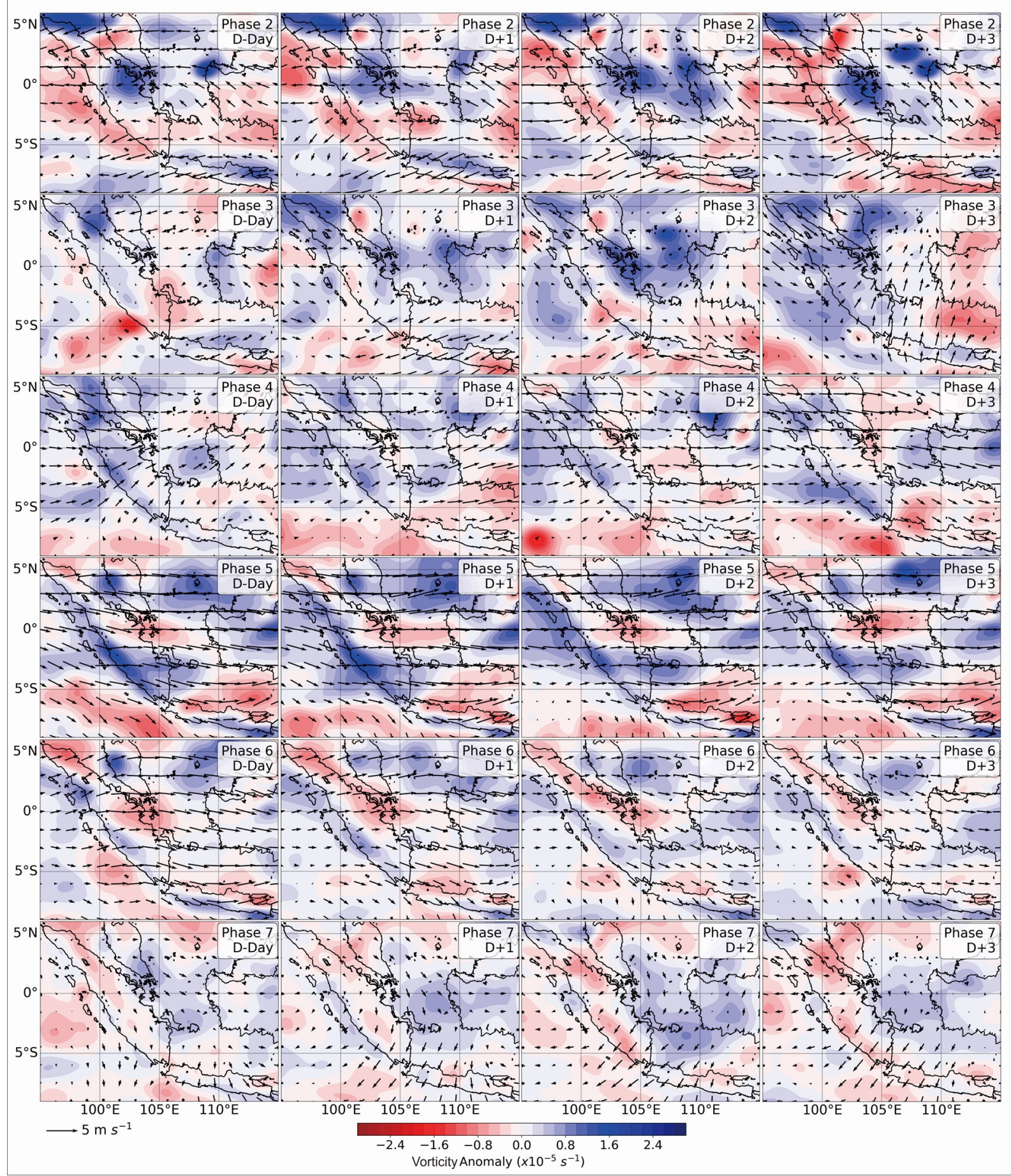

Figure 8: The anomalies and average of absolute vorticity and wind resultant on the day of interaction between CS and MJO, until three days later. 
North Pacific during most MJO events propagating through the MC. These suggestions are true, considering the location of MJO's convective envelope. In periods where the MaddenJulian Oscillation was active in phase 1-3, and western Indonesia is dominated by the easterly anomalies, these anomalies were likely to counter CS's flow, and in turn, be turned to the east, due to coriolis and topographic effect. However, in cases where the region was dominated by westerly anomalies due to MJO phases 4-6, the anomalies were bound to flow in the same way as NCS. Therefore, NCS is in turn able to push MJO in propagating though the MC. This hypothesis is in line with the statement suggesting the strong CS at the equator was probably preventing MJO from propagating the Indian Ocean into the $\mathrm{MC}$ (Xavier et al., 2020), currently dominated by the westerly anomalies.

Positive vorticity anomalies are visible around the study area in the interaction between CS and MJO wet phase, especially around northern Sumatra, Kalimantan, and the southern South China Sea, likely to extend southward up to Karimata Strait. The strengthening of positive vorticity anomalies over the region occurs along with the rise in daily lead time, with a maximum value attained around $\mathrm{D}+2$. This increasing vorticity is mainly affected by the rise in northerlies, due to CS' presence over the area, thus, confirming previous studies (Chang et al., 2005; Lim et al.,
2017) stating Cold Surge is bound to increase shear vorticity around Kalimantan.

In addition to shear, curvature vorticity is likely to be involved in the interaction between the two phenomena. As the wind pattern opposed each other in different levels, 925 $\mathrm{hPa}$ for CS and $850 \mathrm{hPa}$ for MJO, vertical vorticity appears to have an impact as well. Figure 9 shows the vertical cross section of the vorticity anomalies averaged from D-day up to $\mathrm{D}+3$ on each interaction, for zonal and meridional point of views. From the zonal point of view, positive vorticity anomalies were detected in almost every level on the interaction between CS and MJO phases 2-4. These positive anomalies are suppressed to lower levels in the interaction between CS and MJO phases 5-8, with the strongest negative anomalies observed in the upper level on phase 7.

The boundary between positive and negative anomalies is better noticed from the meridional point of view. The lower level positive vorticity anomalies from the north become stronger as the MJO phase enters the study area and attains the most expanded level on the interaction between CS and MJO phase 4 . This vertical pattern of vorticity anomalies gives a similar impression to the $850 \mathrm{hPa}$ vorticity anomalies, indicating the highest rise in vorticity occurs in the interaction between CS and MJO wet phase, from the lower level up, to $100 \mathrm{hPa}$.
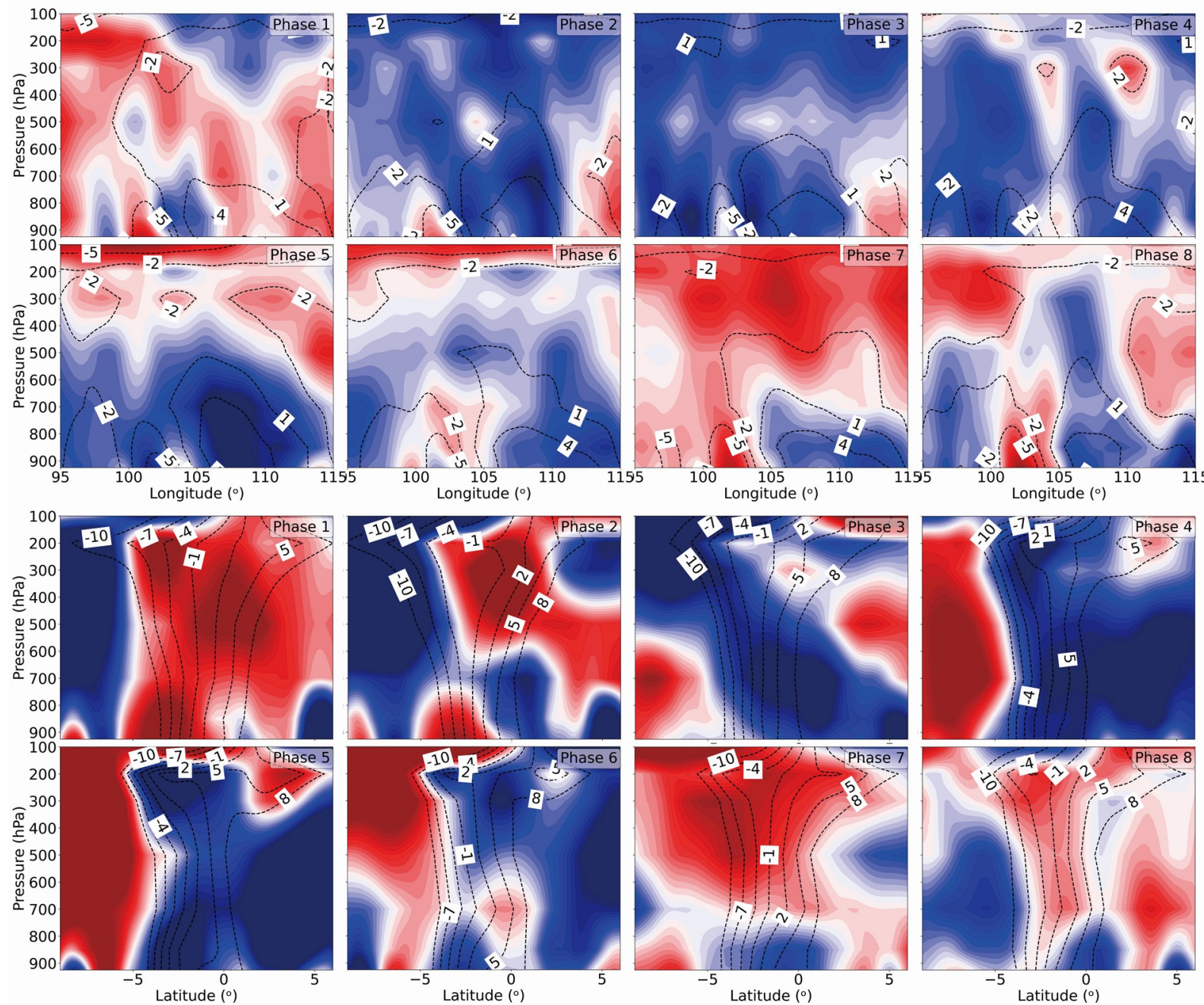

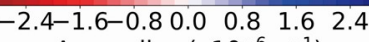

Anomalies $\left(\times 10^{-6} \mathrm{~s}^{-1}\right)$

Figure 9: Vertical - zonal (above) and vertical - meridional (bottom) cross sections of absolute vorticity anomalies averaged for the D-day, up to D+3 after MJO-CS interaction on every MJO phase, over the study area. 
MJO's dominance is also spotted in the vertical cross section of vorticity anomalies. On the lower level, CS' effect on vorticity is better observed (as also shown in $850 \mathrm{hPa}$ ). However, from the vertical cross section, CS' influence is focused to the lower level, while MJO has a bigger impact on the entire atmosphere.

\section{Conclusion}

The MJO increases precipitation over western Indonesia on phases 2-4, but decreases precipitation on phase 5-7. Meanwhile, Cold Surge, affecting a more narrow area, is detected to increase precipitation, for one to three days after reaching $15^{\circ} \mathrm{N}$, especially around Karimata Strait. The interaction between these phenomena is spotted to increase precipitation from the interaction day, until three days afterward.

CS' presence on MJO phases increases the precipitation by about $50 \%$ with maximum value, ranges from about 200 $400 \%$, achieved by areas located over the northeastern coast of Sumatra, around Karimata Strait (Riau Islands and West Kalimantan), and the northern coast of Java, exposed to the sea and with direct access to the wind-terrain or land-sea interaction.

Furthermore, the spatially averaged rainfall anomalies over northern Sumatra, around Karimata Strait, and Java are detected to be maximum in the interaction between Cold Surge and Madden-Julian Oscillation wet phase (phase 2-4), especially around Karimata Strait, with a value of up to 5 $\mathrm{mm} /$ day, followed by northern Sumatra and Java with maximum value of $4 \mathrm{~mm} /$ day and $2 \mathrm{~mm} /$ day, respectively. The interaction is dominated by the MJO effect, as is visible in the $850 \mathrm{hPa}$ wind pattern. In addition, westerly and easterly anomalies from MJO are spotted almost in every phase of the interaction, except phase 7 , where the effect over western Indonesia is less significant. The MJO's dominance is also visible from the vorticity anomalies for almost every level. Therefore, CS affects the lower level vorticity, while MJO appears seems to have a larger impact on the entire atmosphere.

\section{Acknowledgement}

This study received support from the Agency of Meteorology, Climatology, and Geophysics (BMKG) for daily rainfall observation data, as well as from the European Centre for Medium-Range Weather Forecasts (ECMWF) for ERAInterim reanalysis dataset. The authors are also grateful to the Center of Education and Training of Agency Meteorology, Climatology, and Geophysics (Pusdiklat BMKG), for the scholarships provided at Applied Climatology, IPB University.

\section{References}

Abdillah, M. R., Kanno, Y., \& Iwasaki, T. (2018). Tropicalextratropical interactions associated with East Asian cold air outbreaks. Part II: Intraseasonal variation. Journal of Climate, 31(2), 473-490. https://doi.org/10.1175/JCLI-D-17-0147.1

Abdillah, M. R., Kanno, Y., Iwasaki, T., \& Matsumoto, J. (2021). Cold surge pathways in east Asia and their tropical impacts. Journal of Climate, 34(1), 157-170. https://doi.org/10.1175/JCLI -D-20-0552.1

Ahn, M. S., Kim, D., Ham, Y. G., \& Park, S. (2020). Role of maritime continent land convection on the mean state and $\mathrm{MJO}$ propagation. Journal of Climate, 33(5), 1659-1675. https:// doi.org/10.1175/JCLI-D-19-0342.1
Aldrian, E., \& Utama, G. S. A. (2010). Identifikasi dan Karakteristik Seruak Dingin (Cold Surge) tahun 1995-2003. Jurnal Sains Dirgantara. http://jurnal.lapan.go.id/index.php/jurnal_sains/ article/view/667

Becker, E. J., Berbery, E. H., \& Higgins, R. W. (2011). Modulation of cold-season U.S. Daily precipitation by the Madden-Julian oscillation. Journal of Climate, 24(19), 5157-5166. https:// doi.org/10.1175/2011JCLI4018.1

Chang, C. P., Harr, P. A., \& Chen, H. J. (2005). Synoptic Disturbances over the Equatorial South China Sea and Western Maritime Continent during Boreal Winter. Monthly Weather Review, 133, 489-503.

Chang, C. P., \& Lau, K. M. W. (1979). Northeasterly cold surges and near-equatorial disturbances over the winter MONEX area during December 1974. Part I: Synoptic Aspects. In Monthly Weather Review (Vol. 108, Nomor 3, hal. 298-312). https:// doi.org/10.1175/1520-0493(1980)108<0298:NCSANE >2.0.CO;2

Chang, C. P., Lu, M. M., \& Lim, H. (2016). Monsoon Convection in the Maritime Continent: Interaction of Large-Scale Motion and Complex Terrain. Meteorological Monographs, 56, 6.1-6.29. https://doi.org/10.1175/amsmonographs-d-15-0011.1

Chen, X., Li, C., \& Tan, Y. (2017). Further inquiry into characteristics of MJO in boreal winter. International Journal of Climatology, 37(12), 4451-4462. https://doi.org/10.1002/ joc. 5098

Choi, H. Y., Ha, J. H., Lee, D. K., \& Kuo, Y. H. (2011). Analysis and simulation of mesoscale convective systems accompanying heavy rainfall: The goyang case. Asia-Pacific Journal of Atmospheric Sciences, 47(3), 265-279. https://doi.org/10.1007/ s13143-011-0015-X

Darand, M., \& Mirzaei, N. (2018). The relationships between precipitation amounts, number of rain days, and relative vorticity in the mid-troposphere over Iran. Weather, 2005, 1-9. https://doi.org/10.1002/wea.3391

Dee, D. P., Uppala, S. M., Simmons, A. J., Berrisford, P., Poli, P., Kobayashi, S., Andrae, U., Balmaseda, M. A., Balsamo, G., Bauer, P., Bechtold, P., Beljaars, A. C. M., van de Berg, L., Bidlot, J., Bormann, N., Delsol, C., Dragani, R., Fuentes, M., Geer, A. J., ... Vitart, F. (2011). The ERA-Interim reanalysis: Configuration and performance of the data assimilation system. Quarterly Journal of the Royal Meteorological Society, 137 (656), 553-597. https://doi.org/10.1002/qj.828

DeMott, C. A., Wolding, B. O., Maloney, E. D., \& Randall, D. A. (2018). Atmospheric Mechanisms for MJO Decay Over the Maritime Continent. Journal of Geophysical Research: Atmospheres, 123(10), 5188-5204. https:// doi.org/10.1029/2017JD026979

Doswell, C. A., Brooks, H. E., \& Maddox, R. A. (1996). Flash flood forecasting: An ingredients-based methodology. Weather and Forecasting, 11(4), 560-581. https://doi.org/10.1175/1520-0434 (1996)011<0560:FFFAIB $>2.0$. CO;2

Feng, J., Li, T., \& Zhu, W. (2015). Propagating and nonpropagating MJO events over maritime continent. Journal of Climate, 28 (21), 8430-8449. https://doi.org/10.1175/JCLI-D-15-0085.1

Fujita, M., Yoneyama, K., Mori, S., Nasuno, T., \& Satoh, M. (2011). Diurnal convection peaks over the eastern Indian Ocean off sumatra during different $\mathrm{MJO}$ phases. Journal of the Meteorological Society of Japan, 89(A), 317-330. https:// doi.org/10.2151/jmsj.2011-A22

Hattori, M., Mori, S., \& Matsumoto, J. (2011). The cross-equatorial northerly surge over the maritime continent and its relationship to precipitation patterns. Journal of the Meteorological Society of Japan, 89(A), 27-47. https://doi.org/10.2151/jmsj.2011-A02

Heo, J. W., Ho, C. H., Park, T. W., Choi, W., Jeong, J. H., \& Kim, J. (2018). Changes in cold surge occurrence over East Asia in the future: Role of thermal structure. Atmosphere, 9(6), 1-16. https://doi.org/10.3390/atmos9060222

Hidayat, R. (2016). Modulation of Indonesian Rainfall Variability by the Madden-julian Oscillation. Procedia Environmental Sciences, 33, 167-177. https://doi.org/10.1016/ 
j.proenv.2016.03.067

Holton, J. R. (2004). An Introduction to Dynamic Meteorology (4 ed.). Academic Press.

Jeong, Jee Hoon, Ho, C. H., Kim, B. M., \& Kwon, W. T. (2005). Influence of the Madden-Julian Oscillation on wintertime surface air temperature and cold surges in east Asia. Journal of Geophysical Research D: Atmospheres, 110(11), 1-7. https:// doi.org/10.1029/2004JD005408

Jeong, Jong Hoon, Lee, D. I., Wang, C. C., \& Han, I. S. (2016). Characteristics of mesoscale-convective-system-produced extreme rainfall over southeastern South Korea: 7 July 2009. Natural Hazards and Earth System Sciences, 16(4), 927-939. https://doi.org/10.5194/nhess-16-927-2016

Kim, D., Kim, H., \& Lee, M. I. (2017). Why does the MJO detour the Maritime Continent during austral summer? Geophysical Research Letters, 44(5), 2579-2587. https:// doi.org/10.1002/2017GL072643

L'Heureux, M. L., \& Higgins, R. W. (2008). Boreal winter links between the Madden-Julian oscillation and the arctic oscillation. Journal of Climate, 21(12), 3040-3050. https:// doi.org/10.1175/2007JCLI1955.1

Lafleur, D. M., Barrett, B. S., \& Henderson, G. R. (2015). Some climatological aspects of the Madden-Julian oscillation (MJO). Journal of Climate, 28(15), 6039-6053. https://doi.org/10.1175/ JCLI-D-14-00744.1

Li, G., Yang, D., Jiang, X., Pan, J., \& Tan, Y. (2017). Diagnosis of moist vorticity and moist divergence for a heavy precipitation event in Southwestern China. Advances in Atmospheric Sciences, 34(1), 88-100. https://doi.org/10.1007/s00376-0166124-9

Lim, S. Y., Marzin, C., Xavier, P., Chang, C. P., \& Timbal, B. (2017). Impacts of boreal winter monsoon cold surges and the interaction with $\mathrm{MJO}$ on southeast Asia rainfall. Journal of Climate, 30(11), 4267-4281. https://doi.org/10.1175/JCLI-D-160546.1

Matthews, A. J., Pickup, G., Peatman, S. C., Clews, P., \& Martin, J. (2013). The effect of the Madden-Julian Oscillation on station rainfall and river level in the Fly River system, Papua New Guinea. Journal of Geophysical Research Atmospheres, 118(19), 10,926-10,935. https://doi.org/10.1002/jgrd.50865

Muhammad, F. R., Lubis, S. W., \& Setiawan, S. (2021). Impacts of the Madden-Julian oscillation on precipitation extremes in Indonesia. International Journal of Climatology, 41(3), 19701984. https://doi.org/10.1002/joc.6941

Nuryanto, D. E., Pawitan, H., Hidayat, R., \& Aldrian, E. (2019). Characteristics of two mesoscale convective systems (MCSs) over the Greater Jakarta: case of heavy rainfall period 15-18 January 2013. Geoscience Letters, 6(1), 1-15. https:// doi.org/10.1186/s40562-019-0131-5

Pang, B., Lu, R., \& Ling, J. (2018). Impact of cold surges on the Madden-Julian oscillation propagation over the Maritime Continent. Atmospheric Science Letters, 19(10), 1-7. https:// doi.org/10.1002/asl.854

Peatman, S. C., Matthews, A. J., \& Stevens, D. P. (2014). Propagation of the Madden-Julian Oscillation through the Maritime Continent and scale interaction with the diurnal cycle of precipitation. Quarterly Journal of the Royal Meteorological Society, 140(680), 814-825. https://doi.org/10.1002/qj.2161

Pramuwardani, I., Hartono; Sunarto; \& Sopaheluwakan, A. (2018). The Influence of Madden-Julian Oscillation on Local Scale Phenomena over Indonesia during The Western North Pacific and Australian Monsoon Phase. Forum Geografi, 31(December 2018), 156-169. https://doi.org/10.23917/forgeo.v31i2.6226

Pullen, J., Gordon, A. L., Flatau, M., Doyle, J. D., Villanoy, C., \& Cabrera, O. (2015). Journal of Geophysical Research区: Atmospheres rainfall in the Philippines. Journal of Geophysical Research Atmospheres, 120(December 2000), 3292-3309. https://doi.org/10.1002/2014JD022645.Received

Rauniyar, S. P., \& Walsh, K. J. E. (2011). Scale interaction of the diurnal cycle of rainfall over the Maritime Continent and
Australia: Influence of the MJO. Journal of Climate, 24(2), 325348. https://doi.org/10.1175/2010JCLI3673.1

Sudiar, N. Y. (2013). Analisis Periode Ulang Banjir di Kota Padang Menggunakan Cara Iwai dan Kaitannya dengan MJO (Madden Julian Oscillation). Sainstek, V(December 2013), 103-110. https://doi.org/10.31958/js.v5i2.88

Tung, W. W., Giannakis, D., \& Majda, A. J. (2014). Symmetric and antisymmetric convection signals in the Madden-Julian oscillation. Part I: Basic modes in infrared brightness temperature. Journal of the Atmospheric Sciences, 71(9), 33023326. https://doi.org/10.1175/JAS-D-13-0122.1

Wang, L., Kodera, K., \& Chen, W. (2012). Observed triggering of tropical convection by a cold surge: Implications for MJO initiation. Quarterly Journal of the Royal Meteorological Society, 138(668), 1740-1750. https://doi.org/10.1002/qj.1905

Wheeler, M. C., \& Hendon, H. H. (2004). An all-season real-time multivariate MJO index: Development of an index for monitoring and prediction. Monthly Weather Review, 132(8), 1917-1932. https://doi.org/10.1175/1520-0493(2004) 132<1917:AARMMI>2.0.CO;2

Woo, S. H., Kim, B. M., Jeong, J. H., Kim, S. J., \& Lim, G. H. (2012). Decadal changes in surface air temperature variability and cold surge characteristics over northeast Asia and their relation with the Arctic Oscillation for the past three decades (1979-2011). Journal of Geophysical Research Atmospheres, 117(17), 1-16. https://doi.org/10.1029/2011JD016929

Wu, P., Arbain, A. A., Mori, S., Hamada, J. I., Hattori, M., Syamsudin, F., \& Yamanaka, M. D. (2013). The effects of an active phase of the Madden-Julian Oscillation on the extreme precipitation event over western Java Island in January 2013. Scientific Online Letters on the Atmosphere, 9(1), 79-83. https://doi.org/10.2151/sola.2013-018

Xavier, P., Lim, S. Y., Bin Abdullah, M. F. A., Bala, M., Chenoli, S. N., Handayani, A. S., Marzin, C., Permana, D., Tangang, F., Williams, K. D., \& Yik, D. J. (2020). Seasonal dependence of cold surges and their interaction with the madden-julian oscillation over Southeast Asia. Journal of Climate, 33(6), 24672482. https://doi.org/10.1175/JCLI-D-19-0048.1

Xavier, P., Rahmat, R., Cheong, W. K., \& Wallace, E. (2014). Influence of Madden-Julian Oscillation on Southeast Asia rainfall extremes: Observations and predictability. Geophysical Research Letters, 41(12), 4406-4412. https:// doi.org/10.1002/2014GL060241

Zhang, C., \& Ling, J. (2017). Barrier effect of the Indo-Pacific Maritime Continent on the MJO: Perspectives from tracking MJO precipitation. Journal of Climate, 30(9), 3439-3459. https://doi.org/10.1175/JCLI-D-16-0614.1 